\title{
Brief communication: Comparing hydrological and hydrogeomorphic paradigms for global flood hazard mapping
}

\author{
Giuliano Di Baldassarre ${ }^{1,2,3}$, Fernando Nardi ${ }^{4,5,6}$, Antonio Annis ${ }^{4}$, Vincent Odongo ${ }^{1,3}$, Maria Rusca ${ }^{1,3}$, and \\ Salvatore Grimaldi ${ }^{7}$ \\ ${ }^{1}$ Department of Earth Sciences, Uppsala University, Uppsala, Sweden \\ ${ }^{2}$ IHE - Delft Institute for Water Education, Delft, the Netherlands \\ ${ }^{3}$ CNDS - Centre of Natural Hazards and Disaster Science, Uppsala, Sweden \\ ${ }^{4}$ WARREDOC, University for Foreigners of Perugia, Perugia, Italy \\ ${ }^{5}$ Institute of Environment, Florida International University, Miami, Florida, USA \\ ${ }^{6}$ FEEM - Fondazione Eni Enrico Mattei, Milan, Italy \\ ${ }^{7}$ Department for Innovation in Biology, Agro-food and Forest systems (DIBAF), Tuscia University, Viterbo, Italy
}

Correspondence: Giuliano Di Baldassarre (giuliano.dibaldassarre@geo.uu.se)

Received: 18 December 2019 - Discussion started: 23 January 2020

Revised: 9 April 2020 - Accepted: 26 April 2020 - Published: 20 May 2020

\begin{abstract}
Global floodplain mapping has rapidly progressed over the past few years. Different methods have been proposed to identify areas prone to river flooding, resulting in a plethora of available products. Here we assess the potential and limitations of two main paradigms and provide guidance on the use of these global products in assessing flood risk in data-poor regions.
\end{abstract}

\section{Premise}

As economic losses and fatalities caused by river flooding have dramatically increased over the past decades (Winsemius et al., 2016), there has been much progress in the development of analytical tools for the identification of the areas that can be potentially flooded (Ward et al., 2015; Dottori et al., 2018; Nardi et al., 2019). This progress has also been accelerated by the adoption of the Sendai Framework for Disaster Risk Reduction and the Warsaw International Mechanism for Loss and Damage Associated with Climate Change Impacts (Ward et al., 2015). As such, more and more scientists, experts, and practitioners use global floodplain maps in data-poor regions for the identification of flood risk hotspots or the mapping of flood-prone areas (Sampson et al., 2015; Ward et al., 2015; Winsemius et al., 2016; Dottori et al., 2018; Nardi et al., 2019).

\section{Hydrological mapping}

There are two main paradigms to map flooding. The traditional paradigm is (implicitly or explicitly) based on a definition of the floodplain as the area falling within the extent of a given flood event. In this hydrological paradigm, a range of synthetic events with a given probability of occurrence or return period (Pappenberger et al., 2013; Ward et al., 2015; Dottori et al., 2018), such as the 1-in-200-year flood event, is typically estimated via hydrological modelling or statistical analysis of flood data.

This synthetic event is then propagated along the river with hydrodynamic models to estimate the corresponding inundated areas. The hydrological paradigm has been widely used across multiple places and scales (Ward et al., 2015), including large-scale flood hazard modelling in data-poor regions in Africa (Fig. 1). While flood inundation modelling has been successful in simulating historical events (Schumann et al., 2016), large uncertainties come into play when used to simulate synthetic events (Di Baldassarre, 2012). The estimation of a flood hydrograph with a given return period, for example, is extremely uncertain, as time series of flood data are hardly ever available, especially in data-poor areas (Blöschl et al., 2013). Trigg et al. (2016) compared flood maps produced by six hydrological models in Africa and found more disagreement than agreement. 


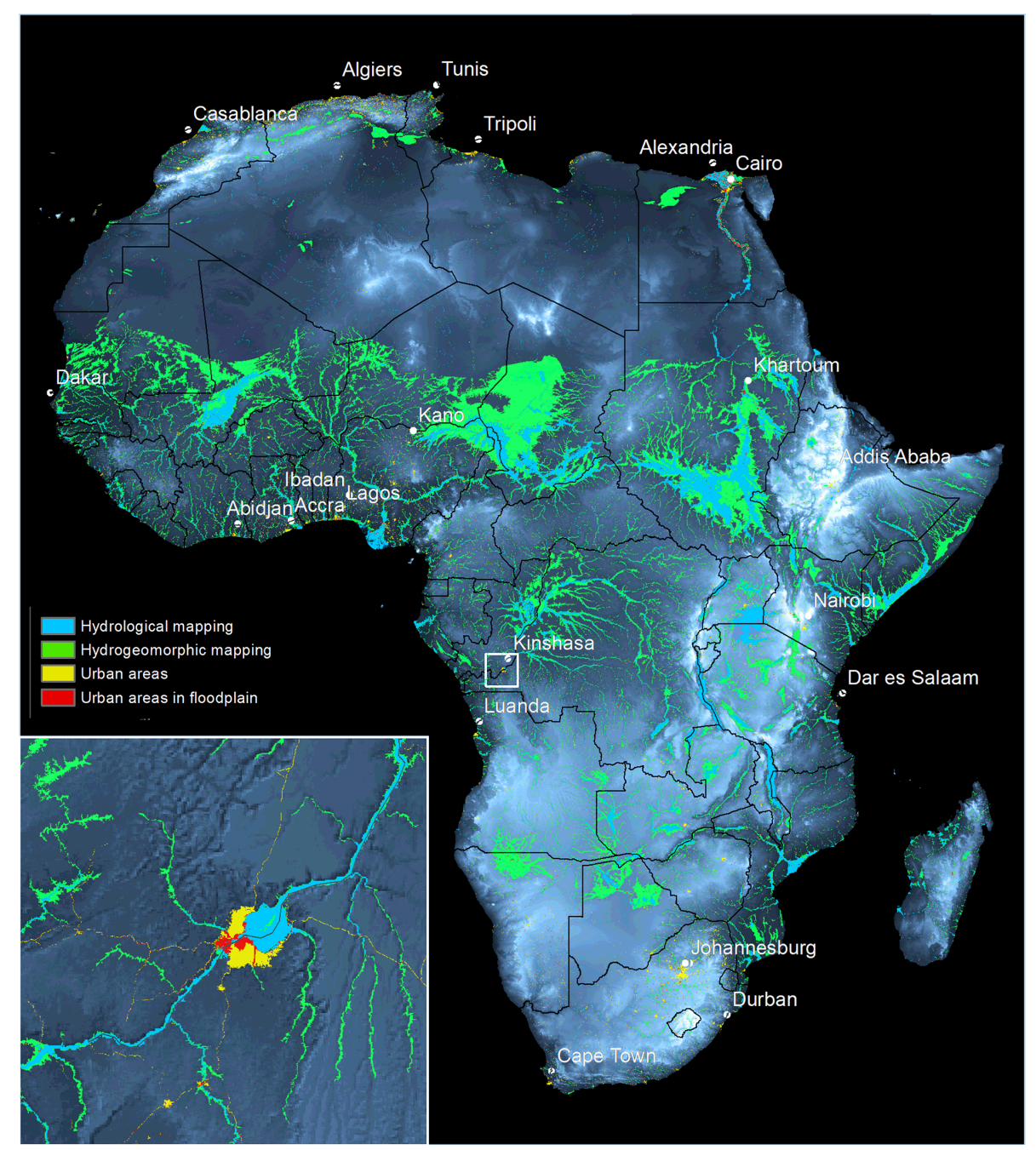

Figure 1. Hydrological vs. hydromorphic flood mapping in Africa. Continental floodplain mapping using an hydrological approach (in blue) with a return period of 200 years (Dottori et al., 2016). The floodplain areas derived with the hydrogeomorphic approach (in green) are based on the GFPLAIN250m dataset4 (Nardi et al., 2019). The inset shows estimated flood-prone areas in Kinshasa (Democratic Republic of the Congo) as well as the Global Man-made Impervious Surface (GMIS) layer (Brown de Colstoun et al., 2017) depicting urban areas (in yellow) and urban areas in floodplains (in red).

\section{Hydrogeomorphic mapping}

An alternative paradigm to map flooding is based on a definition of floodplains as distinguished landscape features that have been historically shaped by the accumulated effects of floods of varying magnitudes and their associated hydrogeomorphic processes (Nardi et al., 2006; Dodov and FoufoulaGeorgiou, 2006). In this hydrogeomorphic paradigm, floodplains are identified directly from the topography (Nobre et al., 2011; Nardi et al., 2019), which is assumed to have been shaped by past flooding events, and building on the concept of fractal river basins (Rodríguez-Iturbe and Rinaldo, 2001) or hydrogeomorphic theories (Bhowmik, 1984; Tarboton et al., 1988). This paradigm does not require the estimation of a synthetic flood hydrograph and consistently identifies flood- prone areas across different places (Manfreda et al., 2014; Nardi et al., 2018; Annis et al., 2019). Also, with the recent development of global digital terrain models (DTMs; Ward et al., 2015; Nardi et al., 2019) and EO-based (Earthobservation-based) cloud computing platforms (Pekel et al., 2016), worldwide mapping of floodplain areas is a reality, and these global maps can be derived from a standard PC with a single click and limited computation time. Hence, it allows easily detecting floodplains, and it is a useful tool for a variety of environmental and socio-economic analyses at a large or global scale. 
Table 1. Advantages and limitations of the two paradigms in mapping floodplain areas.

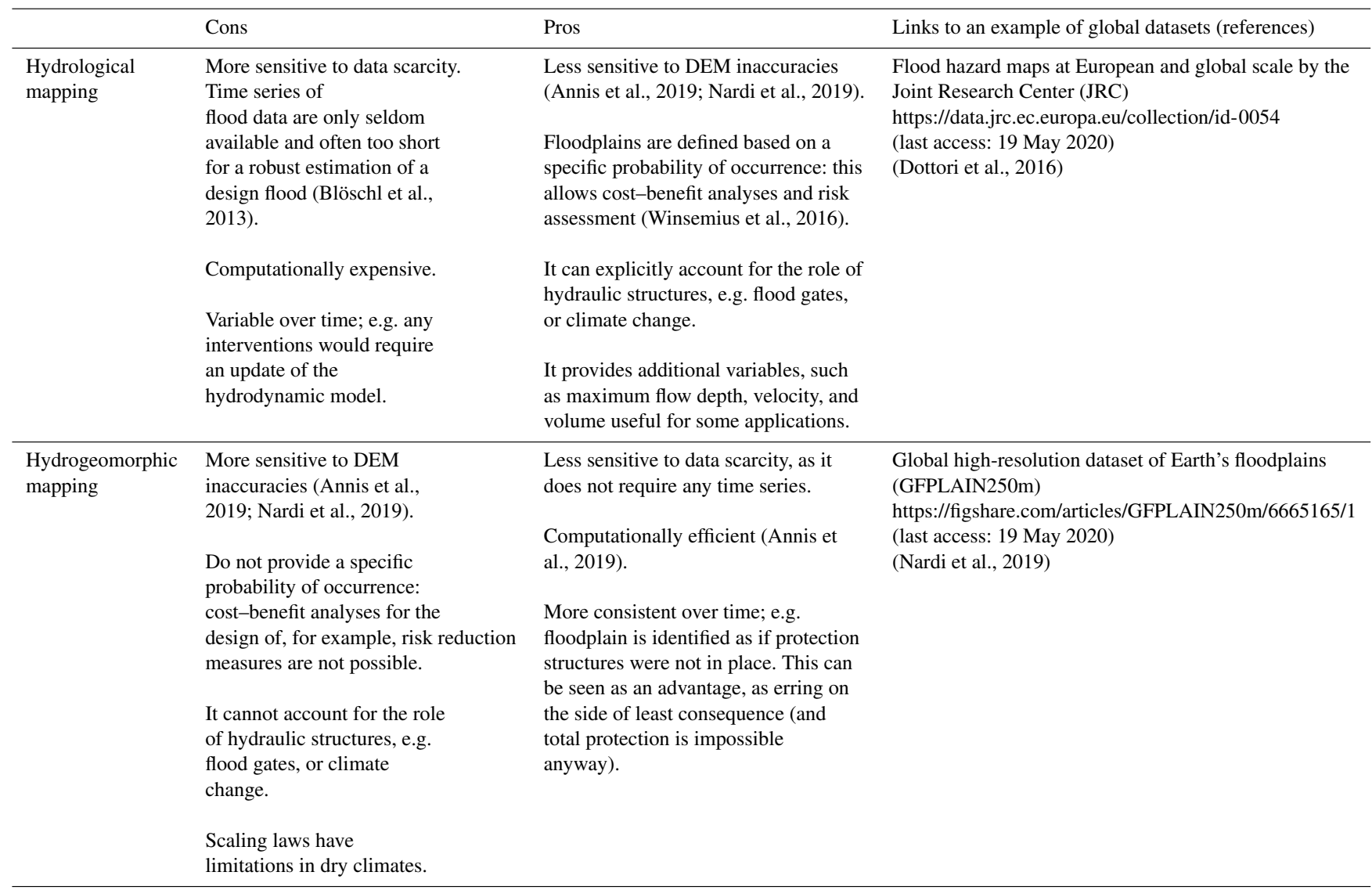

\section{Comparing hydrological and hydrogeomorphic mapping}

Figure 1 shows, as an example, floodplains of the African continent derived with both paradigms (Dottori et al., 2016; Nardi et al., 2019), while its insert compares them in the area around the city of Kinshasa, Democratic Republic of the Congo. International development banks; water sector organizations; and national and international bodies mandated with disaster risk reduction, sustainable development, and humanitarian response use these global maps in data-poor regions for mapping flood risk hotspots (Ward et al., 2015). To provide guidance in using these global products, we list limitations and advantages of the products derived using the two main paradigms in Table 1 . This comparison focuses on the use of these global maps for the identification of flood-prone areas in data-scarce regions. It should be noted that the above paradigms have other purposes than flood mapping. Hydrological mapping is often carried out in order to derive probabilistic hazard metrics for risk assessment (e.g. Winsemius et al., 2016), while hydrogeomorphic maps can be used to support studies of anthropogenic pressure on rivers, such as floodplain connectivity, as well as human-flood interactions (Lindersson et al., 2020).

\section{Conclusions}

Both paradigms are based on consolidated theories, and they have opposite advantages and uncertainties (Table 1). Thus, we argue that these maps are complementary, and they should be exploited following the precautionary principle (Foster et al., 2000), which is an important component of much of the environmental legislation in the Western world. The principle calls for erring on the side of least consequences. In this context, this means that the identification of flood-prone areas in data-poor regions should consider flood inundation areas derived by the two paradigms. The insert of Fig. 1, for instance, highlights (in red) the urban areas falling within the hydrological and/or hydrogeomorphic flood map. While, for the sake of simplicity, our example considered only two global maps, the precautionary principle calls for using all existing flood maps. In this case, the growing availability of EO data (Schumann et al., 2009; Pekel et al., 2016; Lindersson et al., 2020) offers a great potential to test several maps and identify the (most credible) ones that can then be used to estimate flood-prone areas in data-poor regions. 
Data availability. Maps and data are available online and can be accessed using the links provided in Table 1.

Author contributions. GDB, FN, and SG conceptualized the study. AA prepared the figure, with the support of GDB, FN, and SG. GDB wrote the original draft of the brief communication. FN, AA, VO, MR, and SG provided comments and reviewed the original draft.

Competing interests. The authors declare that they have no conflict of interest.

Special issue statement. This article is part of the special issue "Global- and continental-scale risk assessment for natural hazards: methods and practice". It is a result of the European Geosciences Union General Assembly 2018, Vienna, Austria, 8-13 April 2018.

Acknowledgements. This work was developed within the activities of the Panta Rhei research initiative of the International Association of Hydrological Sciences (IAHS). Giuliano Di Baldassarre, Maria Rusca, and Vincent Odongo are supported by the European Research Council (ERC) within the project "HydroSocialExtremes: Uncovering the Mutual Shaping of Hydrological Extremes and Society", Horizon 2020 Excellent Science (consolidator grant no. 761678).

Financial support. This research has been supported by the European Research Council (grant no. 761678).

Review statement. This paper was edited by Hessel Winsemius and reviewed by Francesco Dottori and Guy J.-P. Schumann.

\section{References}

Annis, A., Nardi, F., Morrison, R. R., and Castelli, F., Investigating hydrogeomorphic floodplain mapping performance with varying DTM resolution and stream order, Hydrolog. Sci. J., 64, 525538, 2019.

Bhowmik, N. G.: Hydraulic geometry of floodplains, J. Hydrol., 68, 369-374, https://doi.org/10.1016/0022-1694(84)90221-X, 1984.

Blöschl, G., Sivapalan, M., Savenije, H., Wagener, T., and Viglione, A.: Runoff prediction in ungauged basins: synthesis across processes, places and scales, Cambridge University Press, Cambridge, 2013.

Brown de Colstoun, E. C., Huang, C., Wang, P., Tilton, J. C., Tan, B., Phillips, J., and Wolfe, R. E.: Global Man-Made Impervious Surface (GMIS) Dataset from Landsat, NASA Socioeconomic Data and Applications Center (SEDAC), Palisades, NY, USA, https://doi.org/10.7927/H4P55KKF, 2017.

Di Baldassarre, G.: Floods in a Changing Climate: Inundation Modelling, Cambridge University Press, Cambridge, 2012.
Dodov, B. A. and Foufoula-Georgiou, E.: Floodplain morphometry extraction from a high-resolution digital elevation model: a simple algorithm for regional analysis studies, IEEE Geosci. Remote Sens. Lett., 3, 410-413, https://doi.org/10.1109/LGRS.2006.874161, 2006.

Dottori, F., Salamon, P., Bianchi, A., Alfieri, L., Hirpa, F. A., and Feyen, L.: Development and evaluation of a framework for global flood hazard mapping, Adv. Water Resour., 94, 87-102, https://doi.org/10.1016/j.advwatres.2016.05.002, 2016.

Dottori, F., Szewczyk, W., Ciscar, J. C., Zhao, F., Alfieri, L., Hirabayashi, Y., and Feyen, L.: Increased human and economic losses from river flooding with anthropogenic warming, Nat. Clim. Change, 8, 781-786, https://doi.org/10.1038/s41558-0180257-z, 2018.

Foster, K. R., Vecchia, P., and Repacholi, M. H.: Science and the precautionary principle, Science, 288, 979-981, https://doi.org/10.1126/science.288.5468.979, 2000.

Lindersson, S., Brandimarte, L., Mård, J., and Di Baldassarre, G.: A review of freely accessible global datasets for the study of floods, droughts and their interactions with human societies, Wiley Interdisciplin. Rev.: Water, 7, e1424, https://doi.org/10.1002/wat2.1424, 2020.

Manfreda, S., Nardi, F., Samela, C., Grimaldi, S., Taramasso, A. C., Roth, G., and Sole, A.: Investigation on the use of geomorphic approaches for the delineation of flood prone areas, J. Hydrol., 517, 863-876, 2014.

Nardi, F., Vivoni, E. R., and Grimaldi, S.: Investigating a floodplain scaling relation using a hydrogeomorphic delineation method, Water Resour. Res., 42, W09409, https://doi.org/10.1029/2005WR004155, 2006.

Nardi, F., Morrison, R. R., Annis, A., and Grantham, T. E.: Hydrologic scaling for hydrogeomorphic floodplain mapping: Insights into human-induced floodplain disconnectivity, River Res. Appl., 34, 675-685, 2018.

Nardi, F., Annis, A., Di Baldassarre, G., Vivoni, E. R., and Grimaldi, S.: GFPLAIN250m, a global high-resolution dataset of Earth's floodplains, Scient. Data, 6, 180309, https://doi.org/10.1038/sdata.2018.309, 2019.

Nobre, A. D., Cuartas, L. A., Hodnett, M., Rennó, C. D., Rodrigues, G., Silveira, A., Waterloo, M., and Saleska, S.: Height Above the Nearest Drainage - a hydrologically relevant new terrain model, J. Hydrol., 404, 13-29, 2011.

Pappenberger, F., Dutra, E., Wetterhall, F., and Cloke, H.: Deriving global flood hazard maps of fluvial floods through a physical model cascade, Hydrol. Earth Syst. Sci., 16, 4143-4156, https://doi.org/10.5194/hess-16-4143-2012, 2013.

Pekel, J. F., Cottam, A., Gorelick, N., and Belward, A. S.: High-resolution mapping of global surface water and its long-term changes, Nature, 540, 418-422, https://doi.org/10.1038/nature20584, 2016.

Rodríguez-Iturbe, I. and Rinaldo, A.: Fractal river basins: chance and self-organization, Cambridge University Press, Cambridge, 2001.

Sampson, C. C., Smith, A. M., Bates, P. D., Neal, J. C., Alfieri, L., and Freer, J. E.: A high-resolution global flood hazard model, Water Resour. Res., 51, 7358-7381, https://doi.org/10.1002/2015WR016954, 2015.

Schumann, G., Bates, P. D., Horritt, M. S., Matgen, P., and Pappenberger, F.: Progress in integration of remote sensing-derived 
flood extent and stage data and hydraulic models, Rev. Geophys., 47, RG4001, https://doi.org/10.1029/2008RG000274, 2009.

Schumann, G. J.-P., Neal, J. C., Voisin, N., Andreadis, K. M., Pappenberger, F., Phanthuwongpakdee, N., Hall, A. C., and Bates, P. D.: A first large scale flood inundation forecasting model, Water Resour. Res., 49, 6248-6257, https://doi.org/10.1002/wrcr.20521, 2013.

Schumann, G. J.-P., Stampoulis, D., Smith, A. M., Sampson, C. C., Andreadis, K. M., Neal, J. C., and Bates, P. D.: Rethinking flood hazard at the global scale, Geophys. Res. Lett., 43, 10249-10256, https://doi.org/10.1002/2016GL070260, 2016.

Tarboton, D. G., Bras, R. L., and Rodríguez-Iturbe, I.: The fractal nature of river networks, Water Resour. Res., 24, 1317-1322, https://doi.org/10.1029/WR024i008p01317, 1988.

Trigg, M. A., Birch, C. E., Neal, J. C., Bates, P. D., Smith, A., Sampson, C. C., Yamazaki, D., Hirabayashi, Y., Pappenberger, F., Dutra, E., Ward, P. J., Winsemius, H. C., Salamon, P., Dottori, F., Rudari, R., Kappes, M. S., Simpson, A. L., Hadzilacos, G., and Fewtrell, T. J.: The credibility challenge for global fluvial flood risk analysis, Environ. Res. Lett., 11, 094014, https://doi.org/10.1080/02626667.2013.857411, 2016.
Ward, P. J., Jongman, B., Salamon, P., Simpson, A., Bates, P., De Groeve, T., Muis, S., de Perez, E. C., Rudari, R., Trigg, M. A., and Winsemius, H. C.: Usefulness and limitations of global flood risk models, Nat. Clim. Change, 5, 712-715, https://doi.org/10.1038/nclimate2742, 2015.

Winsemius, H. C., Aerts, J. C. J. H., van Beek, L. P. H., Bierkens, M. F. P., Bouwman, A., Jongman, B., Kwadijk, J. C. J., Ligtvoet, W., Lucas, P. L., van Vuuren, D. P., and Ward, P. J.: Global drivers of future river flood risk, Nat. Clim. Change, 6, 381-385, https://doi.org/10.1038/nclimate2893, 2016. 